therlands) - it was demonstrated that the dog-lead algorithm is by far superior in performance with respect to undershoot, better with respect to sag, and similar with respect to overshoot. Since undershoot is the most severe problem with respect to poor performance, it is suggested that the dog-lead algorithm is of great practical interest.

In greenhouses with a lower and an upper heating pipe network, the temperature can be controlled adequately by using a split-range algorithm.

Adaptive control. Because in a greenhouse the GCFC characteristics are varying, adaptive control can be employed in order to improve the controller behaviour. For the glasshouse used in the above field trial, an adaptive algorithm was designed where the parameter estimation was based on a gradient procedure with asymptotic convergence of the parameter error. Results of the field test - which concludes several years of experience with this adaptive method - indicate clearly that adaptation does not bring a significant improvement.

This paper is based on a doctoral thesis, Agricultural University, Wageningen, 1983. xii +159 pp., 53 figs., 15 tables, 135 refs. English, Dutch summary. One chapter has been published as a paper in International Journal of Control.

Available as paper copy (order R006P, $f 30$ including postage) or microfiches (order R006M, $f$ 17,50 including postage) at: NARD, clo Pudoc, P.O. Box 4, 6700 AA Wageningen, Netherlands (telex 45015 blhwg nl).

\title{
Effects of wider initial spacing of teak (Tectona grandis) on income and income distribution in the taungya system in Java
}

Peter van der Hout (Department of Forest Management, Agricultural University, Generaal Foulkesweg 64, Wageningen, Netherlands)

Accepted: 10 April 1984

\begin{abstract}
Food production, net farm income and net present value increased considerably with a change in initial spacing of teak from $3 \mathrm{~m} \times 1 \mathrm{~m}$ as in the traditional taungya system in Java to $6 \mathrm{~m} \times 1 \mathrm{~m}$. Teak production and financial returns to the State Forest Enterprise decreased only slightly.

Key-words: taungya, teak (Tectona grandis), spacing, financial return, agroforestry, leucaena (Leucaena leucocephala).
\end{abstract}


Introduction. In Java teak plantations are usually established by the taungya system. This system (locally called: tumpangsari) implies that food crops are intercropped between rows of young trees by farmers who are not employed by the State Forest Enterprise, on State Forest land till canopy closure of the stand. Simultaneously with the teak, spacing $3 \mathrm{~m} \times 1 \mathrm{~m}$, a row is sown of the leguminous cover crop Leucaena leucocephala.

From a socio-economic point of view, the taungya system helps to meet the demand for food, encourages use of waste lands and remote areas, and augments the national production by introducing agriculture in forest areas.

Though in Java the system provides satisfactory results, the increasing need for fields raises the question whether present practice can be improved (Atmosoedarjo \& Banyard, 1978; Wiersum, 1982). The purpose of my research was to examine the financial impact of prolongation of the intercropping period by increasing the initial spacing of teak.

Alternative technique. The study used a model based mainly on Indonesian published data. In developing the model, it was stipulated that the altered spacing should cope with the following conditions: prolongation of the intercropping period by another two years by delay in canopy closure; soil deterioration and erosion hazard are not aggravated; development of the stand can be controlled by silvicultural operations; the amount and quality of the product, teak timber, will hardly deviate from the one gained in the traditional practice.

Data from spacing trials show that increasing the initial spacing generally has the following silvicultural effects: the diameter increment of the trees is higher; the production potential of the stand is smaller; thinnings are milder; maintenance operations such as pruning and weeding are more intensive. Financially this means a decrease in costs of establishment and in yields of thinnings and an increase in maintenance costs. In general, foresters are inclined to reject wide spacings because they increase the chance of growth defects, such as forking and heavy branching, and because the number of stems to select from when thinning will be smaller. According to Hart (1928), these advantages arise especially with square and triangular spacings and are of limited effect with row spacings.

The model considers teak cultivation in a 80 -year rotation and intercropping consisting of one crop of rice followed by one crop of maize during each growing season. The main difference between traditional practice and the alternative is enlargement of the initial teak spacing from $3 \mathrm{~m} \times 1 \mathrm{~m}$ to $6 \mathrm{~m} \times 1 \mathrm{~m}$, resulting in 4 years instead of 2 years of intercropping. With row spacing, with intercropping with leucaena and with careful thinning and other maintenance operations (specially pruning), the alternative technique does not harm forest production nor environment, according to the model. At present no experimental data are available to verify these assumptions about the silvicultural implications, but such data should soon be available from current trials in Java (Arifin, 1983).

To compare the two techniques in economic efficiency and socio-economic stability, specially the consequences for the poorer members of society (i.e. landless farmers), some financial parameters were calculated, i.e. net present value at 8,10 
and $12 \%$ interest rates for the State Forest Enterprise and farmer, net farm income and the internal rate of return for the forest enterprise.

Results. According to the model, the total yield of teak is less with the greater spacing than with the traditional spacing because of lower production of first thinnings. The total yield of teak thinnings decreases from about 270 to $150 \mathrm{~m}^{3} / \mathrm{ha}$. The final yield hardly changes. The production of leucaena increases from about 15 to 45 $\mathrm{m}^{3} / \mathrm{ha}$. Leucaena produces fuelwood and fodder, basic needs to the rural population.

Food production is nearly doubled: from 2500 to $4600 \mathrm{~kg} / \mathrm{ha}$ per intercropping period for maize and from 2100 to $3800 \mathrm{~kg}$ /ha for rice. Yields are not exactly doubled because in primitive farming systems yields decrease with consecutive rotations.

The effects of different spacing on the financial parameters, expressed in thousands of Indonesian Rupiah per hectare in one teak rotation ( 80 years), are listed in Table 1.

Table 1. Effects of spacing.

\begin{tabular}{|c|c|c|c|c|c|c|}
\hline \multirow{2}{*}{$\begin{array}{r}\text { Spacing } \rightarrow \\
\text { Interest rate }(\% \text { per year }) \rightarrow\end{array}$} & \multicolumn{3}{|c|}{$3 \mathrm{~m} \times 1 \mathrm{~m}$} & \multicolumn{3}{|c|}{$6 \mathrm{~m} \times 1 \mathrm{~m}$} \\
\hline & 8 & 10 & 12 & 8 & 10 & 12 \\
\hline Net farm income $(\mathrm{Rp} \times 1000 / \mathrm{ha})$ & 323 & - & 306 & 543 & - & 500 \\
\hline \multicolumn{7}{|l|}{ Net present value $(\mathrm{Rp} \times 1000 /$ ha $)$} \\
\hline forest enterprise & 144 & 65 & 30 & 126 & 59 & 30 \\
\hline farmer & 135 & 131 & 127 & 229 & 218 & 209 \\
\hline forest enterprise + farmer & 279 & 195 & 157 & 355 & 278 & 239 \\
\hline
\end{tabular}

The internal rate of return of the forest enterprise is $17 \%$ in one teak rotation with the traditional spacing and $18 \%$ with the alternative.

Conclusion. The financial calculations indicate that enlarging the initial spacing of teak is profitable to the farmer. The forest enterprise, depending on the assumed interest rate, loses nothing or just a little by it. Besides these financial advantages, the alternative technique has the following socio-economic advantages:

- land hunger is relieved in the particular area, also implying that erosion hazard and soil degradation may be diminished in the particular area, because the population pressure on the land surrounding the taungya project is reduced and because teak is partly replaced by soil-improving leucaena;

- basic needs of the rural population are met to a higher degree.

Though data used in the model are not experimental, the outcome of the analysis emphasizes the desirability of examining this alternative, teak spacing $6 \mathrm{~m} \times 1 \mathrm{~m}$, against the traditional technique.

Consequences of other options - like shortening the rotation of teak or a change to species with shorter rotations - for production and income of forest enterprise and farmer, and their environmental impacts have to be studied (Filius, 1981). 


\title{
References
}

Arifin, M., 1983. Enlargement of teak planting space in tumpangsari. Duta rimba (Indonesia) 57/58 (9): 24-26.

Atmosoedarjo, S. \& S. G. Banyard, 1978. The prosperity approach to forest community development in Java. Commonwealth Forestry Review 57(2): 89-98.

Hart, H. J. M., 1928. Stem number and thinning: an orientating research after the best plant distance and way of thinning of teak. Communication 21, Forest Research Institute, Bogor, Indonesia.

Filius, A. M., 1981. Economic aspects of agroforestry. In: K. F. Wiersum, Viewpoints on agroforestry. Agricultural University, Wageningen, Netherlands.

Wiersum, K. F., 1982. Treegardening and taungya in Java. Agroforestry Systems (Netherlands) 1: 53-70.

This synopsis is based on a M.Sc.thesis, Department of Forest Management, Agricultural University, Wageningen, 1983. v +61 pp., 15 tables, 4 figs., 4 appendices, 53 refs. English.

Available as paper copy (order R007P, $f 20$ including postage) or microfiche (order R007M, f 12,50 including postage) at: NARD, clo Pudoc, P.O. Box 4, 6700 AA Wageningen, Netherlands (telex 45015 blhwg $\mathrm{hl}$ ).

\section{Economic aspects of diseases and disease control in dairy cattle, with special reference to reproductive failure}

A. A. Dijkhuizen (Department of Farm Economics, Agricultural University, Hollandseweg 1, $6706 \mathrm{KN}$ Wageningen, Netherlands)

Accepted: 16 May 1984

\begin{abstract}
Some years ago systematic research was initiated to improve quantitative insight into the economic impact of animal diseases and their control. The aim of the present study is to increase this insight by (a) further development of the methods used in this field and (b) performing real quantifications.

Key-words: economics, dairy cattle, reproductive failure, fertility control, replacement.
\end{abstract}

Introduction. The economic impact of animal diseases is determined to a large extent by a combination of three factors, viz the form of disease, the animal species and the economic level(s) considered (Renkema \& Dijkhuizen, 1979). At each quantification it is essential to define these factors accurately, in order to decide which elements to consider and how to place an economic value on them. This study concerns the reproductive failure in dairy cattle, seen from the point of view of an 